Please cite as: Kirs, M., Lember, V. and Karo, E. 2021. Technology Transfer in Economic Periphery: Emerging Patterns and Policy Challenges. Review of Policy Research, https://doi.org/10.1111/ropr.12437.

\title{
Technology Transfer in Economic Periphery: Emerging Patterns and Policy Challenges
}

(Accepted version)

Margit Kirs, TalTech, Nurkse Department of Innovation and Governance; margit.kirs@taltech.ee

Veiko Lember, TalTech Nurkse Department and KU Leuven Public Governance Institute Erkki Karo, TalTech Nurkse Department of Innovation and Governance

\begin{abstract}
Drawing from case studies from the Estonian biotechnology sector, we demonstrate that a focus on the classic formal approach to technology transfer does not fully capture the dynamics and challenges of technology transfer in a peripheral context. We focus on biotechnology because this is an area where entrepreneurial orientation of knowledge institutions and formal models of technology transfer are highly visible. Our case studies show that the knowledge generation and the diffusion contexts of peripheral economies can create barriers to technology transfer that conventional policy approaches do not address.
\end{abstract}

Ke ywords: periphery, te chnology transfer and diffusion, university-industrygovernment relations, biotechnology.

\section{Introduction}

The aspirations behind the entrepreneurial university paradigm and the role of universities as proactive actors in a knowledge-based economy and society are embedded in contemporary innovation policy discourse (Etzkowitz \& Leydesdorff, 2000; Etzkowitz, Webster, Gebhardt, \& Terra, 2000). Somewhat inevitably, policy-makers tend to foresee an 
idealized role for universities in the regional context and in innovation systems in general (Uyarra, 2010; Ooms, Werker, Caniëls, \& Bosch, 2015). European attempts to emulate U.S. rhetoric and practice around technology transfer and commercialization policies have largely failed to account for the fact that the ability to foster entrepreneurial processes of technology transfer is strongly affected by the institutional characteristics of innovation systems (Dosi, Llerena, \& Labini, 2006; Bonaccorsi, 2007; Powell, Owen-Smith, \& Colyvas, 2007; Mowery, 2011; Breznitz \& Etzkowitz, 2016). Wong and Salmin (2015) and Gál and Páger (2018), among others, have demonstrated how the structural problems prevalent in the peripheral innovation systems can threaten the aspirations of the entrepreneurial universities model. However, this article argues that the conflict arising from the mismatch between contextual constraints and policy aspirations in the economic periphery persist partially due to a lack of understanding about exactly how the technology transfer processes evolve and are shaped by specific contexts.

In this study we use the field of biotechnology in Estonia to explore the interlinkages among the entrepreneurial processes, their contexts, and their impacts. Compared to the "old" European Union (EU) member states that form the economic core of the continent, new members from the Central and Eastern European (CEE) region are often regarded as peripheral economies, defined by a focus on capability-building and transition along with a strong dependence on the external politico-economic environment (Narula \& Guimón, 2010). The core-periphery division is a consistent characteristic for both Estonian and the CEE economies more generally, requiring targeted intervention from the national governments to tackle the structural problems prevalent in these economies (Hannula, Radosevic, \& Tunzelmann, 2006). The challenges the CEE countries are facing are exacerbated by the fact that these countries have not only suffered from the simplified reaction to the "European Paradox", but also from the "copying paradox" through the excessive Europeanization of policies, instruments, and organizational solutions (Karo \& Kattel, 2010; Suurna \& Kattel, 2010; Izsak, Markianidou, \& Radosevic, 2014). The Estonian innovation system and its policies have consequently largely followed the linear approach to innovation (Karo \& 
Lember, 2016) which centers the role of academic R\&D in innovation processes, among other developments. Since the field of biotechnology—as a science-based sector (see Pavitt, 1984) — epitomizes this policy logic, this paper uses it as a critical case study for the evolution of the role of academic $R \& D$ in peripheral innovation systems.

In contrast to the prevalent research strategies that focus on technology transfer from the perspective of the academy (Ankrah, Burgess, Grimshaw, \& Shaw (2013)), this article aims to track the influence of contexts on technology transfer from the perspective of the entrepreneur (creation and evolution of new ventures). In doing so, we aim to show the technology transfer patterns that emerge in the Estonian biotechnology sector and how their contexts shape these patterns and their economic impact. The central research question of our study is: How are the knowledge-generation and diffusion sub-systems of university-business technology transfer shaped by peripheral contexts? To answer the research question, we mapped the main technology transfer cases in the Estonian biotechnology field from the past decade; studied the interlinkages between these cases, the main policy strategies, and supporting technology transfer processes in Estonia; and interviewed the main actors (entrepreneurs and entrepreneurial academics).

\section{Technology Transfer in Peripheral Contexts}

The local context of regional and national environments is an important factor affecting sectoral patterns of innovation and development (Malerba, 2002; Tödtling \& Trippl, 2005). Lecocq and Van Looy (2016) explored the key characteristics and types of innovation systems that have been able to develop into the so-called "top regions" in the field of biotechnology. They demonstrate that the success of these regions stems from the combination of scientific eminence, the entrepreneurial orientation of knowledge institutions, and the capabilities of local industry. Below we provide a brief overview of mostly CEEspecific literature on research, development, and innovation (RDI) to illustrate how simplified assumptions about technology transfer that overlook the contextual differences of knowledge creation and diffusion can limit the impact of technology transfer policies and initiatives. 


\section{The Key Challenges in Knowledge Generation}

Among the key issues affecting peripheral economies are their basic RDI capabilities and the nature of prevalent institutional structures and networks (Tödtling \& Trippl, 2005). In terms of technological advancements, peripheral countries are by definition in the catching-up phase (Liagouras, 2010), which is characterized by the dominant role of foreign-made technologies and the respective learning dynamics, and by the relative limited levels of indigenous RDI efforts (Tiits, Kalvet, \& Mürk, 2015). Thus, the RDI policies and public investments in these countries are necessary not only for the advancement of basic R\&D but also for the development of domestic managerial and organizational capabilities for entering international networks "where the new technologies are being hatched" (Mazzoleni \& R. R. Nelson, 2005, p. 9) and for their local adaptation and diffusion (Liagouras, 2010). At the same time, excess emphasis on international cooperation and academic excellence can negatively impact the ability of peripheral countries to meet local socio-economic needs (Qiu, Liu, \& Gao, 2017).

According to A. J. Nelson (2012), the traditional quantitative indicators like patents, licenses, and start-ups only capture the later stages of the innovation cycle. Despite a strong policy emphasis on supporting these formal commercialization processes, the CEE countries witnessed a sharp decrease in new patents during the period between 1990-2009 (Lacasa, Giebler, \& Radosevic, 2017). Therefore, a narrow focus on the formal commercialization of valuable discoveries appears to fail to address more systemic problems of industrial transformations in peripheral economies (Tiits, Kalvet, \& Mürk, 2015; in general, see Salter \& Martin, 2001). Even though most CEE countries have focused on bio-, nano-, and infocommunication technologies in their RDI policies to upgrade their national competitive advantage (Havas, Izsak, Markianidou, \& Radosevic, 2015), their main specializations have become locked into the traditional and sometimes stagnant sectors with declining technological dynamism (Lacasa, Giebler, \& Radosevic, 2017). 
In the peripheral contexts, the most important barriers to technology transfer and innovation-related activities of companies are linked to the availability and quality of human resources and knowledge and also a general reluctance to cooperate with universities (Blažek \& Csank, 2016). Yet, traditional RDI policies still neglect the "softer" end of the technology transfer processes such as the flow of information, skills, expert knowledge, and social capital. These are not easily distinguishable into distinct and formal phases of technology transfer and are more often related to individual academic's incentives (Perkmann et al., 2013). According to different comparative studies, the spin-off creation concerns only a minority of academics in specific disciplines, while different consultation and collaboration activities tend to be more widespread (Perkmann et al., 2013; Salter \& Martin, 2001; Bekkers \& Bodas Freitas, 2008). Furthermore, in academic career and management models, the status of research valorization via technology commercialization and spin-off formation remains secondary, at least in comparison to scientific excellence measures like publications and citations (Philpott, Dooley, O’Reilly\& Lupton, 2011; de Jong, Smit, \& van Drooge, 2016).

As a result, the greatest challenge for CEE countries seems not to be related to the intermediary structures of R\&D institutions still in an embryonic phase as reflected in problems from internal arrangements to human and financial resources (Blažek \& Csank, 2016, pp. 1107-1109). Rather, the main challenges for CEE countries are the unstable governance of publicly funded research and, in particular, the decrease in direct (institutional) public funding of basic research (Lepori et al., 2009; in general, see OECD, 2019).

\section{The Key Challenges in Technology Diffusion}

Technology transfer through venture creation should not be seen as a discrete process, but as one that is related to the wider issues of connections between supply and demand environments, as well as the respective knowledge transfer and absorptive capacities (Bozeman, 2000; Polt et al., 2001). Therefore, one should look beyond the early stages of venture development and elements such as the discovery and identification of commercial opportunity, the role of champions, and the capabilities for resource acquisition (Rasmussen, 
Mosey, \& Wright, 2014). Particularly important are the processes of post-formation product development and growth of spin-off companies, their capacities to adapt to changing environmental conditions, and the ability to form relationships with customers (Djokovic \& Souitaris, 2008; Perez \& Sanchez, 2003; in general, Teece, Pisano, \& Shuen, 1997). In this context, the lack of critical capacities in business organizations, like managerial skills, access to finance, employee training, the organization of production, marketing, and distribution functions, is one of the crucial differences between leading and peripheral economies (Liagouras, 2010). These capacity deficiencies are often accompanied by structural problems in developing trust, networking, inter-organizational relationships, and local embeddedness (Tödtling \& Trippl, 2005).

While the key factor in establishing university-industry collaborations is finding innovative companies with which to collaborate (Muscio \& Vallanti, 2014), the nature of $\mathrm{R} \& \mathrm{D}$ demand is another significant barrier to the technology transfer processes in the peripheral context. This is primarily due to the prevailing need for routine services over more innovative content (Blažek \& Csank, 2016). Nevertheless, the emphasis on R\&D-centric entrepreneurial policies in the current circumstances of basic capacity-building is believed to have very little economic impact and perhaps even a highly detrimental impact in the longterm (Liagouras, 2010).

Lee \& Kang (2010) have shown how national profiles of productive specialization tend to determine the specific modes for technology transfer. The prevalence of informal and relatively less complex transfer practices is not only a particular characteristic of developing and emerging economies, but also constitutes an inevitable step in progressing toward more complex and formal type of interactions between academia and industry. In this context, the creation of spin-off companies is seen as a reaction to the low absorptive capacity of the local demand environment, while contract research, joint R\&D projects, and open science presume a certain level of in-house R\&D capability (Lee \& Kang, 2010). The aforementioned aligns somewhat with the Pisano's (2006) argument that intensified business activities in the segment of young and small companies should be seen as an indicator of immaturity and 
vulnerability prevailing in the biotechnology industry. This also reflects the variations of university-industry linkages along with technology and industry life cycles (Polt et al., 2001; Bodas Freitas, Marques, \& Silva, 2013).

The coordination of supply and demand contexts are challenging in biotechnology, as research and early exploitation of newly created knowledge tend to be highly regionalized while the development, distribution, and marketing are highly globalized (Kaiser \& Prange, 2003). The research on CEE countries has already highlighted the development problems due to the uneven integration of national innovation systems with both national and global production and innovation networks (Carayannis, Varblane, \& Roolaht, 2012; Radosevic \& Stancova, 2015). The dependence on foreign value-chains and trends dictated by wider economic structures and relationships also makes it rather difficult to change the nation-state specific specializations through local policies alone (Karo et al., 2014).

\section{The Socio-Institutional Context of Technology Transfer}

Largely following the thinking of "varieties of capitalism" (Hall \& Soskice, 2001), the final aspect that researchers highlight in the context of peripheral economies concerns the politico-economic conditions and legacies that pose specific challenges for the pace and nature of technological progress and for the economic behavior in the system. The development of supportive institutional settings presumes strategic interactions, coordination, and collaboration among the public- and private-sector actors to understand the needs of and complementarity in capabilities of different actors (Hall \& Soskice, 2001). Among other framework conditions, also technological specialization and structure of the economy, property right regimes, incentive mechanisms to support innovation, access to financial capital, and closeness to technology markets have been highlighted (Hall \& Soskice, 2001; Karo \& Looga, 2014; Lee \& Kang, 2010).

One can argue that the lack of embeddedness in state and society relationships has been the most challenging issue for the supportive policy-making routines to emerge in CEE. 
However, the impact of differing institutional trajectories in different countries needs to be acknowledged here as well (Karo \& Looga, 2014; Suurna \& Kattel, 2010; Karo \& Kattel, 2010). The mechanical transfer of Western policy models, together with the focus on commercialization and university-industry cooperation, has been not only the most common but arguably also the most legitimate avenue for policy-making (Radosevic, 2011, p. 36). This approach, however, did not always allow these countries to tackle the main problems they faced (Suurna \& Kattel, 2010). As the technology-transfer policies in the "West" tend to focus on developing different intermediary institutions and on the direct and formal economic benefits of technology transfer (Bozeman, Rimes, \& Youtie, 2014), the congruence of supply and demand conditions has proven to be particularly problematic in the current policylearning context of CEE (Karo \& Lember, 2016). This explains, in turn, why the issues of basic capacity-building and broader impact and public value have received only limited attention.

The dependence on the EU structural funds as a primary source for RDI policy in CEE countries should be added to this discussion (Ferry, 2017). Because the key strategy of the CEE governments has been to maximize absorption of the EU funds, procedural correctness and transparency along with a strong reliance on a project-based approach and relatively short-term timeframes have become the central characteristics of the RDI-related institutional climate instead of the strategic impacts (Ferry, 2017). Since private sector investments (venture capital, in particular) play a significant role in bridging science and markets in the field of biotechnology (McKelvey, 2004; in general, Hall \& Soskice, 2001), there seems to be a strong mismatch between the specific nature of science-based sectors and the institutional support system prevalent in CEE. These countries are unable to provide the funding or the technical expertise and network externalities needed by the sector to manage heavy risks, uncertainty and long lead-times. The market-based coordination mechanisms have arguably failed to provide an institutional environment supportive of the long-term development of the biotechnology sector even in the developed countries, as the result of which the debate about 
the role of the state as "a lead market-creating investor" has become more prominent (Pisano, 2006; Lazonick \& Tulum, 2011; Mazzucato, 2013).

\section{Summary}

From the systemic perspective, technology transfer through business venture creation should be treated as a dynamic and multi-step process combining knowledge generation with knowledge exploitation and diffusion. One of the typical characteristics of the peripheral innovation systems is the limited cohesion between knowledge generation and exploitation contexts. The greater the differences in the specializations and capabilities of universities and economic sectors, the more policy efforts, time, and investments are needed to induce longterm cohesion between the knowledge-generation and diffusion sub-systems and to increase the socio-economic impact of technology transfer. Table 1 summarizes the key issues of technology transfer in the peripheral context of CEE economies and provides conjectures for the empirical study of the Estonian biotechnology field.

Table 1. The Key Issues of Technology Transfer in the Peripheral Context

\begin{tabular}{|c|c|c|}
\hline $\begin{array}{l}\text { Contexts of } \\
\text { technology transfer }\end{array}$ & $\begin{array}{l}\text { Key drivers of technology } \\
\text { transfer }\end{array}$ & $\begin{array}{l}\text { Conjectures on the key systemic barriers to } \\
\text { technology transfer in the peripheral context }\end{array}$ \\
\hline \multirow[t]{2}{*}{$\begin{array}{l}\text { Knowledge } \\
\text { generation }\end{array}$} & $\begin{array}{l}\text { Fundamental know ledge base for } \\
\text { technology transfer }\end{array}$ & $\begin{array}{l}\mathrm{C} 1 \text { : Highly dependent on the access to } \\
\text { international networks } \\
\mathrm{C} 2 \text { : Underemphasis on the role of fundamental } \\
\text { research in the technology transfer processes }\end{array}$ \\
\hline & $\begin{array}{l}\text { The acceptance of variety in } \\
\text { forms and patterns of technology } \\
\text { transfer }\end{array}$ & $\begin{array}{l}\text { C3: Strong emphasis on commercialization in } \\
\text { the context of low patenting activity } \\
\text { C4: Low emphasis on tacit and human resource } \\
\text { related university-industry interface }\end{array}$ \\
\hline
\end{tabular}




\begin{tabular}{|c|c|c|}
\hline & $\begin{array}{l}\text { The entrepreneurial orientation of } \\
\text { universities }\end{array}$ & $\begin{array}{l}\text { C5: Poorly developed organizational structures } \\
\text { and incentive mechanisms to facilitate the } \\
\text { change tow ard more applied research and } \\
\text { technology transfer } \\
\text { C6: Limited attention to academic engagement } \\
\text { and incentive mechanisms at the individual level }\end{array}$ \\
\hline \multirow[t]{2}{*}{$\begin{array}{l}\text { Knowledge } \\
\text { exploitation and } \\
\text { diffusion }\end{array}$} & $\begin{array}{l}\text { The general level of local demand } \\
\text { for } R \& D\end{array}$ & $\begin{array}{l}\text { C7: Low domestic demand and overwhelming } \\
\text { reliance on international value chains } \\
\text { C8: The lack of disciplinary congruence } \\
\text { between know ledge generation and diffusion } \\
\text { sub-systems } \\
\text { C9: Low demand for innovation and R\&D based } \\
\text { services }\end{array}$ \\
\hline & $\begin{array}{l}\text { The absorption and dynamic } \\
\text { capacities of local enterprises }\end{array}$ & $\begin{array}{l}\text { C10: Overwhelming emphasis on R\&D-centric } \\
\text { capacities and not on building basic business } \\
\text { capacities (absorptive capacities) } \\
\text { C11: Proportionally high attention given to } \\
\text { establishing new business ventures and not to } \\
\text { their grow th and sustainability }\end{array}$ \\
\hline \multirow[t]{2}{*}{$\begin{array}{l}\text { Socio-institutional } \\
\text { context }\end{array}$} & $\begin{array}{l}\text { The suitability of the prevailing } \\
\text { policy mix }\end{array}$ & $\begin{array}{l}\text { C12: R\&D priorities and policy measures } \\
\text { limited to cutting-edge technologies } \\
\text { C13: Reliance on international "best practice } \\
\text { models" and trends in designing policies and } \\
\text { institutions, including RDI funding }\end{array}$ \\
\hline & $\begin{array}{l}\text { The public value and impacts of } \\
\text { technology transfer }\end{array}$ & $\begin{array}{l}\text { C14: Comparatively large emphasis on } \\
\text { measurability (compounded by the limits in } \\
\text { indicators in use for the analysis and evaluation } \\
\text { of innovation systems) }\end{array}$ \\
\hline
\end{tabular}

Source: Authors.

\section{Research Design and Methodology}

\section{The Case Selection}


This study selected the biotechnology sector to test the theoretical conjectures in the science-based regime where one could expect technology transfer to be most natural and visible (see Pavitt, 1984; Gilsing, Bekkers, Bodas Freitas, \& van der Steen, 2011). The Estonian innovation system is a good candidate for a more detailed analysis of the peripheral context, especially because of the explicit mismatch between the knowledge generation and exploitation sub-systems and related questions about the modalities for technology-transfer processes. Four key challenges to technology transfer in Estonia are outlined below.

The first key challenge involves the contradictions between political targets of knowledge-intensive innovation system and real national productive developments. Since 2002, biotechnology, along with ICT and nanotechnologies, has been explicitly prioritized in all national RDI strategies in Estonia; today, it is one of the smart specialization priority areas (Knowledge-based Estonia 2002-2006, 2007-2013, and 2014-2020). During this same period, Estonia also experienced a significant per capita GDP growth, which has basically doubled since 2000. However, this growth has not been accompanied by the economic restructuring and specialization into higher value-added activities of the traditional industrial fields, which remain the major players in the national economy (Karo et al., 2014; European Commission, 2019). The private sector demand for $R \& D$ remains concentrated in the hands of an extremely small group of local enterprises (e.g. Mürk \& Kalvet, 2015), suppressed by generally low levels of employment for specialists with doctoral degrees in the sector (Niinemets, 2019).

Second, despite Estonia being "a poster child for successful transition to Western-style science" (Nature, 2009) and high rankings in academic publishing, the number of international patent applications filed in Estonia has decreased since 2005. While the overall scientific capacities of Estonia, in terms of publications and citations, are concentrated in fields related to biotechnology, mainly molecular biology, genetics, microbiology and biochemistry (Allik, 2016), the total number of U.S. utility patents granted to Estonian biotech scientists accounts for only around $10 \%$ of all U.S. patents granted to entities involving Estonian inventors. As of October 2016, biotech accounted for 37 out of 326 patents (authors, based on OECD, 2017 and EPO, 2017). This has been paralleled by the limited patenting 
activity by local enterprises, at least in comparison to local researchers and universities as well as institutions and companies registered abroad. This trend is also reflected in the limited income from technology transfer for the Estonian public research institutions, especially in the fields of bio- and environmental sciences (Kirs, Karo, \& Lumi, 2017). The last argument is particularly surprising given that the primary focus of the national RDI strategies has been on developing different measures for technology transfer and commercialization by setting up technology transfer offices in universities to revising patent and licensing laws and funding joint R\&D networks and projects (Karo, 2010; Suurna \& Kattel, 2010).

Third, the Estonian biotechnology industry experienced rapid expansion between 2007 and 2014, when significant EU funding was directed to the field's RDI through the Knowledge-based Estonia Strategy and the Estonian Biotechnology Program. During that time, more than half of the companies that identify their main activity as biotechnology $R \& D$ were established. In the majority of cases, this refers to micro-enterprises that in one way or another can be affiliated with the main public R\&D institutions in Estonia (Kirs, 2016; Suurna, 2011). Based on the companies' strong orientation towards service provision (consultancy, business services and sales) (see Lukason, Mõttus, \& Varblane, 2014), there appears to be comparatively limited importance of codified knowledge as well as the shortterm and concrete deliverable-based cooperation patterns prevailing between the R\&D institutions and industry (see also Lember et al., 2015).

The final challenge involves how the financial environment affects developments in Estonia's biotechnology sector. This primarily concerns the heavy dependence on EU structural funds and the firms' own sales revenues (realization-based financing scheme), while the private sector expenditure on R\&D has lagged behind (Ernst \& Young, 2010; Kirs, 2016; Bank of Estonia, 2017). In contrast to the financial systems that have emerged in Western countries, the biotechnology sector in Estonia does not enjoy the leverage of earlystage equity investors, which were basically non-existent until 2018 (European Investment Bank, 2018) nor from the network externalities generated by large companies in similar 
activities (in particular, the non-existence of big pharma and the low absorptive capacity of local industry) (Ernst \& Young, 2010; European Commission, 2019).

\section{The Sample and Data Sources}

In our study, we focused on the entrepreneurial processes underlying technology transfer and how these are shaped by the knowledge generation, exploitation, and policy contexts. To generate observable socio-economic impact (by financial indicators and/or expert assessments), we concentrated on the evolution of successful business ventures that have grown out of the Estonian R\&D system during the past two decades. The ten sample cases (in detail, see Appendix 1) were selected to cover the most important biotechnology research and enterprise groupings in Estonia (Kirs 2016; Kirs, Karo, \& Lumi, 2017) in addition to the entire range of possible mechanisms for technology transfer (see Brown, 2016), such as sponsored research, licenses, spin-off companies, student start-ups, and human capital. In our analysis of the Estonian biotechnology sector, we developed four stylized examples to illustrate the most prevalent models for technology transfer as derived from the specificity of knowledge generation and diffusion sub-systems in the peripheral context (see Figure 1).

\section{Figure 1. Stylized Examples of Technology Transfer in the Field of Biotechnology in}

\section{Estonia}

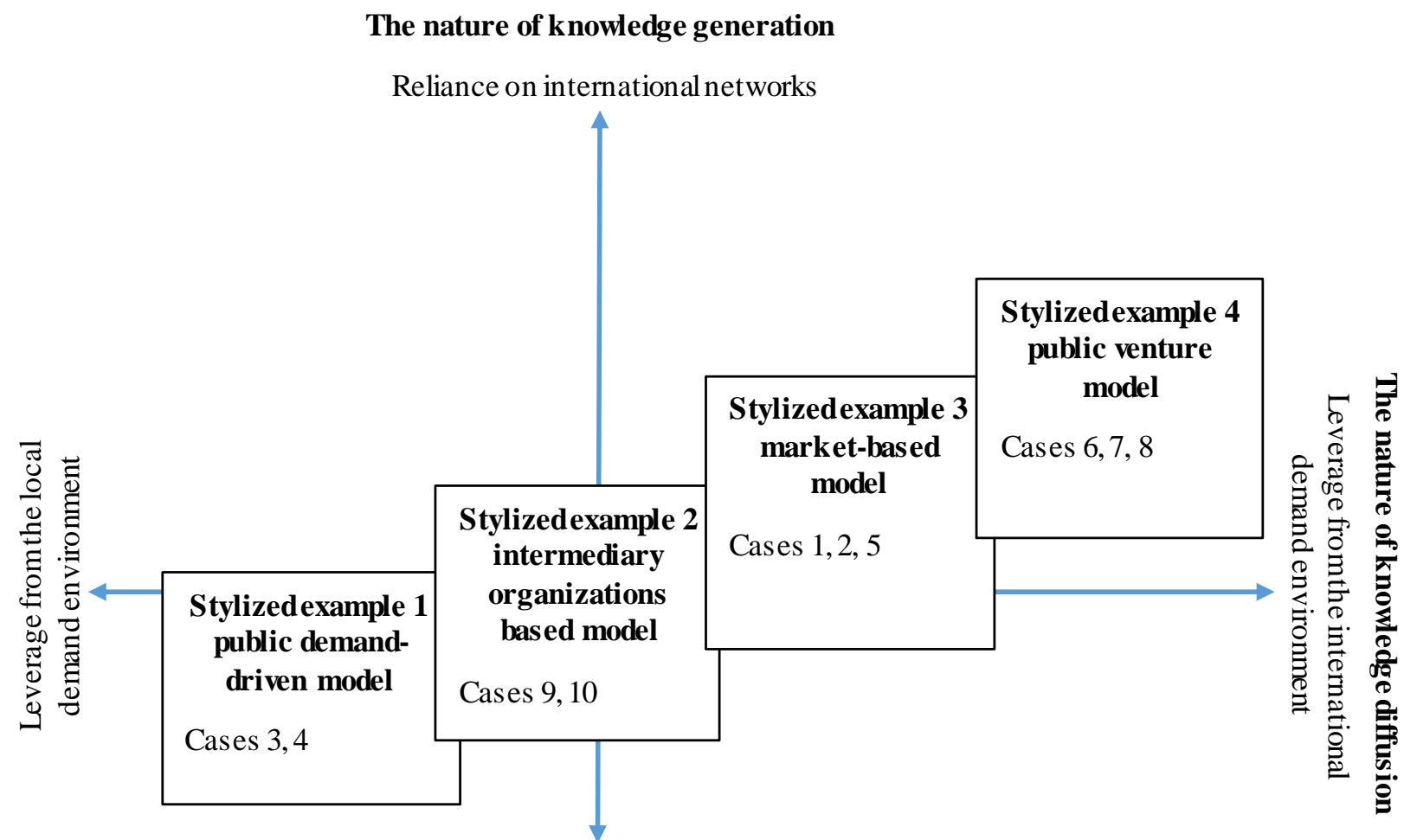


Local embeddedness

Source: compiled by Authors; for detailed information about the cases, see Appendix 1.

For the empirical analysis, we conducted extensive desk research covering media reports and financial activities of the related organizations based on the Estonian Commercial Register (Äriregister) to detect and analyze the evolution of the successful cases of technology transfer. Second, we conducted interviews with R\&D managers from all major enterprise groups and government-financed biotechnology competence centers to gather further details and participants' perceptions on the main factors influencing technology transfer and diffusion in the Estonian biotechnology sector. To better understand relationships between the academic and business spheres, we carried out additional interviews with the leaders of different biotechnology research groups. Altogether, we conducted interviews with representatives from 20 organizations.

In the following sections, we first provide a summary of stylized case studies that characterize the four identified patterns of technology transfer in the Estonian biotechnology field and then test and discuss the theoretical conjectures presented in Table 1.

\section{Stylized Case Studies}

\section{Stylized Example No 1 - Public Demand-Driven Model}

This model illustrates primarily the technology transfer processes in the field of molecular-diagnostics technologies and methods (e.g. DNA tests, technologies to diagnose specific pathogens) that appear to fit neatly into a classic linear model. Codified knowledge alone, however, has played only a supportive role in the selected case studies. The importance 
of tacit knowledge is reflected in the crucial role of transfer of key persons from the research groups to the business ventures, especially because the underlying knowledge was not always reduced to the written format.

In terms of knowledge generation, the research group leaders' previous stays in the international environment (primarily in the US, for education and employment) should be emphasized. These international stays provided researchers with a crucial basis for taking the lead in advancing the particular scientific disciplines in Estonia, but also for opening up certain so-called "windows of opportunities" to meet or co-create specific needs in the local market.

The fate of the respective companies has been dependent on the early decoupling from the public R\&D system and the inclusion of professional managers from the business sector to establish functional business models, which included the division of tasks, service delivery models, production facilities, and quality management systems, among other functions. The early support measure for technology transfer by the Innovation Fund (the predecessor of 'Enterprise Estonia', the key state agency for the implementation of innovation policy and for managing EU funding) in the late 1990s seems to have supported this. The innovation funding included both a grant to the R\&D institution to cover the time for transfer (including the wages for researchers) and a loan to the corporation to cover the development expenses, which acted, in turn, as an enforcement mechanism to speed up the processes.

Another aspect illustrating the knowledge exploitation context concerns the leverage from the local demand environment, which is particularly crucial for most of the spin-offs in Estonia that are highly dependent on service-dominant logic. While developing the diagnostic services, the key supporting national demand-side actor has been the governmental Health Insurance Fund of Estonia (the main health insurance provider) whose decisions to include certain procedures and methods on the list of reimbursed services has enabled several new technologies to emerge and also allowed several start-up companies to connect with first customers in the early stages of development. Because the lobby of medical associations and organized physicians are crucial in influencing these choices of the Fund, their early inclusion 
in technology transfer attempts, awareness of technological advancements, and demonstration of cost-efficiency to hospitals and clinics are important aspects of demand management. As the spin-off companies in question show some of the highest sales revenues and export capacities of the field (see Kirs 2016), one can argue that the access to the stable nation-wide demand base has been the key success factor-not only for the growth in local markets, but also for scaling up internationally.

\section{Stylized Example 2 - Intermediary Organizations Based Model}

The key examples of this model come from food technologies (from functional food to fermentation processes and the respective software). The model includes the activities of the respective competence centers, specifically the collaboration platforms to match supply and demand for new technologies of the field, such as the Competence Center of Food and Fermentation Technologies and Bio-Competence Center of Healthy Dairy Products, in particular, and the commercialization of Probiotic Bacteria Lactobacillus Fermentum ME-3. As outlined by Lee \& Kang (2010), codified knowledge has played a greater role in the food technologies sector than in other sectors because of the maturity of the food industry, which has provided a more stable basis for defining the need for specific applications and for formalizing these transfers through patents and licenses. In congruence with this, technology transfer offices and competence centers have served as the primary channels for the aforementioned technology transfer processes. In all these cases, the formal transfer of technology has been complemented by the partial movement of the research groups (including the leaders in some cases) from universities to competence centers and by the ongoing informal interactions, respectively.

The underlying knowledge basis for technology transfer in these particular cases has emerged from extended periods of fundamental research dating back to the 1990s, with strong roots in international projects and collaborations, and has been complemented by the local food industry. Participation in international R\&D cooperation projects has not only enabled 
access to front-line technology developments in the field, but has also provided the significant public funding necessary for entrepreneurial discovery processes as well.

Additionally, in terms of knowledge exploitation, the partnerships with internationally well-recognized corporations (like Lallemand, DuPont, and Valio, among others) have been particularly crucial in guaranteeing certain financial stability for the efforts by satisfying the more small-scale needs and fragmented needs of the local market. In comparison to the other models, the role played by the local market has been somewhat exceptional in the case of the food industry in Estonia, which was suppressed the most by the EU regulatory influence during the accession period. So, while somewhat over-eager transfer and strict interpretation of the EU regulations and sanitary requirements during the late 1990s and early 2000s limited the space for technology diffusion and applications in the domestic food market, the external pressures of the EU rules and regulations also acted as an incentive to increase the cooperation between companies and the R\&D institutions, including competence centers. Hence, one can argue that the concurrent closure of several domestic food companies and the fierce competition in a small local market acted as important drivers for building competitive advantage based on $R \& D$ cooperation.

According to the key stakeholders from $\mathrm{R} \& \mathrm{D}$ institutions, the more profound impacts of the respective joint research projects remain limited, especially due to the great volatility embedded in the local business environment and the lack of prioritization of in-house R\&D activities by the entrepreneurial side. Paradoxically, the success story of commercialization of ME-3 bacteria can be viewed as a primary example illustrating the complexity of the involved processes. The pilot project funded by Enterprise Estonia was particularly critical here in tackling the aforementioned demand-side challenges, not only for mitigating the financial risks in the project, but also for establishing certain confidence in the respective undertaking in the business sector.

The state support of competence centers (the Competence Center of Food and Fermentation Technologies and Bio-Competence Center of Healthy Dairy Products) via Enterprise Estonia confirms the importance of mechanisms supporting academia-business 
cooperation in the form of independent and private law entities that bring together both codified and tacit knowledge and mutually beneficial interests of the field. While the competence centers active in the food industry have received the strongest credit for their potential self-financing capacity in the national mid-term evaluations (Enterprise Estonia, 2018), only a limited number of firms in the sector are actively engaged in the activities of competence centers in Estonia. Hence, the potential for wider technology transfer and socioeconomic impact remains limited here as well.

\section{Stylized Example 3 - Market-Based Model}

This section covers cases focused on commercialization of analytical capabilities in the fields of synthetic organic chemistry and molecular biology that are well developed at the Estonian universities. The prevalent mode for technology transfer in these particular cases has been strongly tacit and informal in nature, involving the transfer of staff and their know-how and qualifications. Only in certain limited cases does knowledge transfer also involve license agreements for the technology developed at the university. The initiation of these business ventures has been defined by a strongly applied research focus, whereas the founding team generally involved academic entrepreneurs, people with backgrounds in working with different technology transfer projects (either in the respective units at universities or independent institutions such as technology parks), and investors. In turn, the specialization of the companies into service provision as opposed to the development of original products explains the limited importance of codified knowledge.

The embeddedness of international $\mathrm{R} \& \mathrm{D}$ networks is also highly relevant here, but it is considered foremost as a ground for establishing relationships with the first core customer and as an important gateway to global value chains. Hence, the social network of a founding team functions essentially as a crucial starting ground in this model. As most initiatives investigated in this section are related to the pharmaceutical industry and rely upon "exitstrategies" in their business models, following the industry's investment interests and possible future prospects at the global level further exacerbates the local embeddedness. 
The specific feature for technology diffusion in this model is guided by high expectations associated with competition in the international market, while the local potential is considered to be limited and has remained underexploited. In practice, the realization of this kind of strategy has been particularly challenging for spin-off companies due to the fierce competition and volatility prevalent in the area of service provision (while relying upon favorable price-quality ratio as a prevailing competitive advantage, in particular). A crucial success factor in this model is building trust in the venture's service provision capacities from day one. The cross-usage of infrastructure in cooperation with $\mathrm{R} \& \mathrm{D}$ institutions and science parks has helped mitigate the initial risks, while the market demand for large-scale production capacities has further suppressed the growth ambition of the ventures in question. As a rule, the collaboration with the public R\&D system tends to be cut off mainly because of the business secrecy and IP involved in the processes. There are only a few companies in this sector that have managed to establish themselves as specialized service providers in the global value chains. The competitive advantage of these particular cases relies upon the development of specific technology platforms, enabling the provision of standard services at the niche markets and also involves stronger complementarity for R\&D advancements from the local knowledge environment.

The impact of state support measures (in particular, those provided by Enterprise Estonia) remains more varied in this group of business ventures. In the majority of cases, the support measures have not been essential for technology transfer to take place. Moreover, there were also companies in this sample that received no support from the state. If used, the support measures by Enterprise Estonia are considered to be critical to survive the period of financial crisis, but also for opening new R\&D lines. In general, one can say that the success of the business ventures in this group is largely dependent on marketing capacities, which is highly challenging in the context of reliance on service delivery and contract research with multinationals.

\section{Stylized Example 4 - Public Venture Model}


The cases covered in this section are directly related to the pharmaceutical industry, ranging from gene therapy and personalized medicine to point-of-care medical devices. In all these cases, formal technology transfer remains limited in the Estonian context. The informal relationships to academia as well as to the founding member's business experience and networks at the international level are the most significant considerations in these cases. Local embeddedness is stronger when relying on the specific competence of the research group; otherwise, the respective companies could have been established anywhere.

The origin and ownership of the underlying technology for services and products of these particular cases tends to remain outside Estonia. Frequently, technology transfer has started from the contract research for international companies that has led to the establishment of a branch office or an independent company in Estonia. By contrast, there are also companies that have elected to cooperate with foreign partners, especially when the local universities lack the required basic capabilities and technologies.

In a knowledge exploitation context, the local platforms for industry and academia interface like competence centers have played a very limited role. However, the common characteristic in all these cases is the substantive influence from different public funding agencies. Locally, both the support measures from Enterprise Estonia and the investments and partnerships by the state-owned investment fund, Estonian Development Fund (currently closed down and their portfolio of investments has been taken over by its subsidiary AS SmartCap) stand out in the several companies in this model. Internationally, the financial support by the Finnish innovation agencies (including TEKES) and the Development Bank of Saxony (AufbauBank SAB) have been key sources of financing for the technology transfer initiatives. In the latter case, the developments have led to the establishment of subsidiaries in Germany together with a stronger reliance on external R\&D competences.

One can debate the extent to which the local funding mechanisms have facilitated the technology transfer in these cases. The allocations by Enterprise Estonia have arguably remained small, especially in comparison to the $R \& D$ investments and the long lead time needed in the biotechnology sector. By contrast, the financial support at the international level 
seems to have played a more substantive role. The stronger international focus is also driven by the highly regulated international environment in the respective area (the European Medicine Agency's authorization, in particular). As a result, the local markets may be considered to be too small for the investments to pay off.

As in all cases outlined in this model, product development is still in process. It can be argued that both local and international public sector investments are particularly important in cases where the overall demand for biotechnology transfer from university to industry is weak and indirect.

\section{Discussion of Results}

After reviewing the Estonian cases, it's clear that focusing on a narrow formal approach to technology transfer and reinforcing this through policy rhetoric does not fully support the substantive technology and knowledge transfer and capabilities development.

\section{The Impact of the Knowledge Generation Context}

The Estonian case study has demonstrated that technology transfer processes with some concrete impact have concentrated around the research themes and groups with a high level of research excellence and strong international networks. In several cases, the underlying basis for technology transfer emerged from rather long periods of fundamental research going back to 1990s. Given that stable governmental funding was found to be highly supportive of intensifying university-industry linkages at the individual and research group levels (Perkmann et al., 2013), the decline in Estonian public sector expenditure on R\&D to 0.66\% of GDP in 2017 (European Commission, 2019) is worrisome. This tendency is eroding local public research capacity and also has the potential to limit the ability to break up the Matthew effect in international scientific collaboration networks, in which the segregation 
among the CEE countries and the old EU member states still prevails (Ukrainski, Kanep, Kirs, \& Karo, 2018).

At the same time, the primary emphasis on advancing international academic excellence in Estonia has relegated the relevance of meeting the local needs for technological development to secondary importance, as warned by Qiu, Liu, \& Gao (2017). This tendency is further suppressed by the limited willingness and capacities of the private sector to reorient the prevalent $R \& D$ activities of the local universities towards more experimental and applied ones. One of the results of this mismatch is the increasing number of companies that aim to build stronger relationships with foreign $R \& D$ partners, especially because the local universities are perceived to lack the necessary capabilities.

While the Estonian RDI policies emphasize the linear and formal technology-transfer model, we managed to map only a few successful spin-off companies and ready-made "outthe-door" solutions that could validate the effectiveness of this policy approach. The prevailing pattern of technology transfer in the Estonian biotechnology sector seems to be strongly tacit and informal. This pattern occurs primarily through the transfer of competent people (entrepreneurial academics who are shareholders and/or R\&D consultants in the spinoff companies, qualified personnel, and graduates), even in the cases that at first sight seem to fit neatly into the format of a classic linear model. A limited group of single entrepreneurial academics played the most important role in the transfer processes, influencing it with their personal aspirations, goals and interests. In all cases, we speak about scientists "well established and well connected in the academic community" (see Perkmann et al., 2013, p. 429). Hence, the challenge remaining in Estonia concerns the development of incentive mechanisms supportive of technology transfer at both the organizational and individual level. Such incentives might include career rewards, sabbaticals, and mobility schemes for researchers (see also OECD, 2019).

\section{The Impact of the Knowledge Exploitation and Diffusion Context}


In several cases (models 2 and 3, in particular), the lack of a local pharmaceutical industry, as well as fragmented demand from the local food industry, are considerable barriers in the local demand context. This is most vividly demonstrated by the fact that most successful knowledge transfer cases have been funded (at least partly) by the public sector through the Enterprise Estonia, Estonian Development Fund/AS SmartCap, foreign national development banks, and foreign innovation agencies). In other words, it is the supply-push financing logic that has played a central role in the initiation of most of the Estonian biotechnology transfer cases and provided a basis for early experimentation with lower risks. The importance of public demand, like the decisions by the national Health Insurance Fund of Estonia, has been another favorable factor for technology diffusion, which was a particularly prominent feature in model 1. In line with the overall export-oriented development strategy of Estonia, however, several spin-off companies have targeted competition in the international market. The other issue here concerns the change of ownership (from local to foreign) of some promising spin-off companies, especially due to the need for patient (public) funding during the phase of more intensive applied R\&D activities.

While the spin-off creation is seen as an important driver of national competitiveness in the knowledge-based economy (OECD, 2019), one can ask: ,what is the public value of the quantitative expansion of spin-off companies if their growth and ability to scale up tends to be restricted by the business environment?" This is what Bozeman, Rimes, \& Youtie (2014) might identify as a classic example of economic benefits-led technology-transfer policies ("was the technology transferred?"), relegating the wider issues of public-value and impact ("was it beneficial?") to secondary concern. In other words, the narrow focus on spin-off creation is worrisome in the Estonian biotechnology context where either reliance on contract research or "subsidy-dependency" - detectable in some spin-off cases-has become key to survival in the biotechnology industry in Estonia (see Kirs, 2016). Essentially, spin-off companies face a vicious cycle of development prospects where they need to abandon academic routines and hire people with a business background (like marketing or sales), but the companies are too small and fragile to take the required risks. 
Further, the spin-off creation as a specific mode for technology transfer is reflective of firms' weak absorptive capacity and the lack of cohesion between academia and industry, which includes a lack of proper understanding of the other's needs and capabilities (Lee \& Kang, 2010). The Estonian case has demonstrated that spin-off creation alone is not able to overcome the demand environment-related challenges, and may exacerbate the challenges in the adaptation processes even further. The roots of the aforementioned problems can be traced back to the major prioritization of high technologies instead of more traditional fields in the national policies, which is a trend that can have negative effects on national innovation systems in developing countries (see Bodas Freitas, Marques, \& e Silva 2013). In fact, the low absorptive capacity of industry and the fact that the current industry's structure is overly dominated by small firms with little $R \& D$ were identified as the central challenges for the development of the Estonian RDI system in the European Commission's most recent evaluation report (2019).

Finally, the successful examples of technology transfer in Estonia have required both academic and business-related leverage from international financial and knowledge networks, which highlights the importance of high research and managerial capabilities (like relationships with customers and suppliers and organizational culture) over technology transfer capabilities. While one of the key aspects identified in the cases concerns the early decoupling from the public R\&D system, another important issue is the support mechanisms (e.g. policy instruments for piloting and experimentation) for building confidence in and facilitating technology transfer processes by business enterprises. The latter issue remains relatively underemphasized both in Estonian policy rhetoric and more generally (see OECD, 2019).

\section{The Impact of the Socio-Institutional Context}

Essentially, the problem presented in this study is a classic outcome of the "copying paradox", which explains that the focus on and belief in single-policy measures generates expectations that are difficult to fulfil within the existing academic and business contexts. The 
key challenge is to find the synergies between these two contexts, which is obviously a long and learning-inte nsive process, making it considerably less attractive in comparison to other "ready-made" solutions for cooperation. The successful cases of biotechnology transfer identified in this study date back to the late 1990s and early 2000s when the policy support structures were still in their infancy. Thus, the success of the technology transfer cases should be seen as a result of several important factors working together, including the "real" demand for R\&D, which was implemented in practice via the inclusion of medical doctors as consultants in the research groups. Another important consideration is that many of first biotechnology spin-off companies were founded essentially as personal 'pet projects' of key people behind the companies.

The efforts to magnify the formalized university-business interactions via different intermediary units have had only a limited impact in bridging the gap of capabilities in the two sectors in Estonia. In the context of limited patenting activity, the real implications of policy rhetoric on technology transfer offices remain particularly controversial in Estonia, especially as the operational basis of these units is believed to be highly dependent on the object of technology transfer and the extent to which it can be codified by the people involved. In fact, the technology transfer offices are considered to be one of the least important channels for knowledge transfer, even in developed countries (Bekkers \& Bodas Freitas, 2008). On the other hand, the policy measure to create cooperation platforms between academy and industry via competence centers has been somewhat exceptional in Estonia as it was the only effort to identify and sustain new organizational routines and capabilities for technology transfer. Nevertheless, the measure's wider impact on technology transfer processes and socio-economic development remains limited, especially as there are competitive pressures and interests that keep these entities closed to other actors.

The previous aspects also underscore the need to acknowledge technology transfer as a dynamic process that starts from informal small-scale consulting and evolves towards more contractual relationships and joint $R \& D$ projects, while the prevalence of a particular stage for technology transfer is argued to be dependent on the country's specific conditions and level of 
economic development (see Lee \& Kang, 2010). As the fundamental problems in these different stages are diverse and constantly changing, the design of policy initiatives is correspondingly a highly complex and demanding task.

In sum, an analysis of the varieties in knowledge generation and diffusion policies is important for advancing the current debates around technology transfer. Further research and the development of sector-specific policies should take into account issues related to technology life cycles and demand context, including the existence of local supporting industries and the nature of value chains in the industry.

\section{Conclusion}

The goal of this study was to provide an in-depth overview of the knowledge generation and diffusion sub-systems relevant to technology transfer processes in the peripheral contexts of CEE economies. In order to do so, the conjectures about contextspecificity in peripheral economies were proposed and tested in a technology field where one could expect technology transfer to be most visible. In circumstances in which the primary focus of national RDI strategies in CEE is on developing different measures for technology transfer and commercialization in science-based regimes, the study provides strong evidence about how the specific nature of these processes is affected by locally weak demand environments and absorptive capacities.

In the context of knowledge generation, this study has demonstrated that the technology transfer processes with a significant impact have converged around the research themes and groups with a high level of research excellence and strong international networks. Hence, building basic R\&D capacities is clearly a more crucial component in technology transfer processes in CEE than simply a concentration on commercialization of codified knowledge. 
In the context of knowledge diffusion, the substantive influence of different funding agencies (both local and international) was detected both during and after the foundation period of spin-offs. The role of public-sector investments is particularly evident in the context of success stories, due to the provision of a certain stability for early experimentation and the resulting stronger basis for scaling-up and internationalization. In addition to the advantage from local, public demand, building the absorptive capacities of the system was also identified as crucial, especially since the successful technology transfer processes tend to rely upon high-level research and managerial capabilities rather than technology transfer capabilities.

The socio-economic impact of technology transfer depends on how policy-makers are able to take into account the structural and context-specific aspects of technology transfer. So far, the fundamental problems of technology transfer tend to be treated as common for different industrial sectors and innovation systems, but also for different actors in the innovation system. The particular challenges identified in this study concern the underemphasis of the role of individual academics and business-oriented policy instruments, in contrast to the overemphasis on "ready-made" solutions for facilitating technology transfer processes. This study recommends building a comprehensive policy approach for tackling a wide range of challenges facing the various actors involved in the processes. A move away from simplistic copying of international best practices towards a context-specific, problembased, and actor-centric approach could be a starting point.

\section{References}

Allik, J. (2016). Scientific publications: Estonia rises to the top. In J. Allik, U. Varblane \& T. Tammaru (Eds.), Estonian Research 2016 (pp. 27-32). Tartu: Estonian Research Council.

Ankrah, S. N., Burgess, T. F., Grimshaw, P., \& Shaw, N. E. (2013). Asking both university and industry actors about their engagement in knowledge transfer: What single-group studies of motives omit. Technovation, 33(2-3), 50-65. 
The Bank of Estonia. (2017). Financing of the Economy. The Annual Report. Retrieved from http://www.eestipank.ee/en/publications/series/lending-review (accessed 25 September 2019).

Bekkers, R., \& Bodas Freitas, I. M. (2008). Analyzing knowledge transfer channels between universities and industry: To what degree do sectors also matter? Research Policy, 37(10), 1837-1853.

Blažek, J., \& Csank, P. (2016). Can emerging regional innovation strategies in less developed European regions bridge the main gaps in the innovation process? Environment and Planning C: Government and Policy, 34(6), 1095-114.

Bodas Freitas, I. M., Marques, R. A., \& e Silva, E. M. P. (2013). University-industry collaboration and innovation in emergent and mature industries in new industrialized countries. Research Policy, 42(2), 443-453.

Bonaccorsi, A. (2007). Explaining poor performance of European science: Institutions versus policies. Science and Public Policy, 34(5), 303-316.

Bozeman, B. (2000). Technology transfer and public policy: A review of research and theory. Research Policy, 29(4-5), 627-655.

Bozeman, B., Rimes, H., \& Youtie, J. (2014). The evolving state-of-the-art in technology transfer research:Revisiting the contingent effectiveness model. Research Policy, 44(1), 34-49.

Breznitz, S. M., \& Etzkowitz, H. (Eds.) (2016). University Technology Transfer: The Globalization of Academic Innovation. Routledge Studies in Global Competition. London, NY: Routledge Taylor \& Francis Group.

Brown, R. (2016). Mission impossible? Entrepreneurial universities and peripheral regional innovation systems. Industry and Innovation, 23(2), 189-205. 
Carayannis, E. G., Varblane, U., \& Roolaht, T. (Eds.) (2012). Innovation Systems in Small Catching-Up Economies: New Perspectives on Practice and Policy. London: Springer Science+Business Media LLC.

de Jong, S. P. L., Smit, J., \& van Drooge, L. (2016). Scientists' response to societal impact policies: A policy paradox. Science and Public Policy, 43(1), 102-114.

Djokovic, D., \& Souitaris, V. (2008). Spinouts from academic institutions: A literature review with suggestions for further research. Journal of Technology Transfer, 33(3), 225-247.

Dosi, G., Llerena, P., \& Labini, M. S. (2006). The relationships between science, technologies and their industrial exploitation: An illustration through the myths and realities of the so-called 'European Paradox'. Research Policy, 35(10), 1450-1464.

Enterprise Estonia. (2018). Enterprise Estonia supports research and innovation. Press release of 21 of December 2018. Retrieved from https://www.eas.ee/eas-toetabteadusarendust-ja-innovatsiooni// (accessed 20 May 2019).

Eom, B.-Y., \& Lee, K. (2010). Determinants of industry-academy linkages and, their impact on firm performance: The case of Korea as a latecomer in knowledge industrialization. Research Policy, 39(5), 625-639.

EPO (European Patent Office). (2017). Statistics (database). Retrieved from https://www.epo.org/about-us/annual-reports-statistics/statistics.html\#national (accessed 17 December 2017).

Ernst \& Young. (2010). Estonian biotechnology programme: Feasibility study for an Estonian biotechnology programme. Innovation Studies, 13, 1-130.

Etzkowitz, H., \& Leydesdorff, L. (2000). The dynamics of innovation: From national systems and 'Mode 2' to a triple helix of university-industry-government relations. Research Policy, 29(2), 109-123. 
Etzkowitz, H., Webster, A., Gebhardt, C., \& Terra, B. R. C. (2000). The future of the university and the university of the future: Evolution of ivory tower to entrepreneurial paradigm. Research Policy, 29(2), 313-330.

European Commission. (2019). Peer Review of the Estonian R\&I System. Final Report. Retrieved from https://rio.jrc.ec.europa.eu/en/library/peer-review-estonian-researchand-innovation-system-final-report (accessed 25 September 2019).

European Investment Bank. (2018). EIF and EstFund committed EUR 60 million for investments into Estonian SMEs. Press release of 2 of July 2018. Retrieved from https://www.eif.org/what_we_do/equity/news/2018/eif-kredex-eur-60m-estfund.htm (accessed 25 September 2019).

Ferry, M. (2017). The role of EU funds in enhancing the development potential of CEE economies. In B. Galgóczi \& J. Drahokoupil (Eds.), Condemned to Be Left Behind? Can Central and Eastern Europe Emerge from its Low-wage Model? (pp. 153-170). Brussels: European Trade Union Institute.

Gál, Z., \& Páger, B. (2018). The changing role of universities and the innovation performance of regions in Central and Eastern Europe. In G. Lux \& G. Horváth (Eds.), The Routledge Handbook to Regional Development in Central and Eastern Europe (pp. 225-239). Abingdon, NY: Routledge Taylor \& Francis Group.

Gilsing, V., Bekkers, R., Bodas Freitas, I. M., \& van der Steen, M. (2011). Differences in technology transfer between science-based and development-based industries: Transfer mechanisms and barriers. Technovation, 31(12), 638-647.

Hall, P. A., \& Soskice, D. (Eds.) (2001). Varieties of Capitalism: The Institutional Foundations of Comparative Advantage. Oxford: Oxford University Press.

Hannula, H., Radošević, S., \& Tunzelmann, N. (Eds.) (2006). The New EU Economy. Building a Baltic Miracle? Hampshire, Burlington: Ashgate Publishing Ltd. 
Havas, A., Izsak, K., Markianidou, P., \& Radosevic, S. (2015). Comparative analysis of policy-mixes of research and innovation policies in Central and Eastern European countries. GRINCOH Working Paper Series (Serie 3: Knowledge, Innovation, Technology), 3.12,1-60.

Izsak, K., Markianidou, P., \& Radosevic, S. (2014). Convergence of national innovation policy mixes in Europe - has it gone too far? An analysis of research and innovation policy measures in the period 2004-12. JCMS: Journal of Common Market Studies, 53(4), 786-802.

Kaiser, R., \& Prange, H. (2003). The reconfiguration of national innovation systems - The example of German biotechnology. Research Policy, 33(3), 395-408.

Karo, E. (2010). Improving governance of science and innovation policies, or just bad policy emulation? The case of the Estonian R\&D system. Halduskultuur-Administrative Culture, 11(2), 174-201.

Karo, E., \& Kattel, R. (2010). The copying paradox: Why converging policies but diverging capacities for development in Eastern European innovation systems? The International Journal of Institutions and Economies, 2(2), 167-206.

Karo, E., Kattel, R., Tõnurist, P., Valdmaa, K., Looga, L., Kirs, M., Lumi, P., \& Käger, M. (2014). Estonian Research Funding Instruments and the Socio-Economic Impact of Publicly Funded Research in Estonia. Research and Innovation Policy Monitoring Programme (2012-2015): Final Report of the Workpackage 5.1. Estonia: Tallinn University of Technology.

Karo, E., \& Lember, V. (2016). Emergence of a societal challenges based innovation policy in market-based innovation systems: Lessons from Estonia. International Journal of Foresight and Innovation Policy, 11(1-3), 126-147.

Karo, E., \& Looga, L. (2014). Understanding institutional changes in economic restructuring and innovation policies in Slovenia and Estonia. Journal of International Relations and Development, 19(4), 500-533. 
Kirs, M. (2016). Expansion of science-based industries: Technological and organizational accumulation vs. fragmentation? Insights from biotechnology in Estonia. International Journal of Technological Learning, Innovation and Development, 8(4), 303-344.

Kirs, M., Karo, E., \& Lumi, P. (2017). Strategic behaviour of research groups within the entrepreneurial university policy rhetoric: The Estonian biotechnology sector. Science and Public Policy, 44(6), 802-820.

Lacasa, I. D., Giebler, A., \& Radosevic, S. (2017). Technological capabilities in Central and Eastern Europe: An analysis based on priority patents. Scientometrics, 111(1), 83-102.

Lazonick, W., \& Tulum, Ö. (2011). US biopharmaceutical finance and the sustainability of the biotech business model. Research Policy, 40(9), 1170-1187.

Lecocq, C., \& Van Looy, B. (2016). What differentiates top regions in the field of biotechnology? An empirical study of the texture characteristics of biotech regions in North America, Europe, and Asia-Pacific. Industrial and Corporate Change, 25(4), $671-688$.

Lee, K., \& Kang, R. (2010). University-industry linkages and economic catch-up in Asia. Millennial Asia, 1(2), 151-169.

Lember, V., Karo, E., Kirs, M., Tõnurist, P., Valdmaa, K., Mäekivi, R., \& Hanson, R. (2015). Relevance of Research and Development and Innovation Policy for the Real Economy. Research and Innovation Policy Monitoring Programme (2012-2015): Final Report of the Workpackage 5.2. Estonia: Tallinn University of Technology.

Lepori, B., Masso, J., Jabłecka, J., Sima, K., \& Ukrainski, K. (2009). Comparing the organization of public research funding in Central and Eastern European countries. Science and Public Policy, 36(9), 667-681.

Liagouras, G. (2010). What can we learn from the failures of technology and innovation policies in the European periphery? European Urban and Regional Studies, 17(3), $331-349$. 
Lukason, O., Mõttus, M., \& Varblane, U. (2014). Support Systemfor Spin-OffCompanies in Estonia. Research and Innovation Policy Monitoring Programme (2012-2015): Final Report of the Workpackage 4.4. Estonia: University of Tartu.

Malerba, F. (2002). Sectoral systems of innovation and production. Research Policy, 31, 247264.

Mazzucato, M. (2013). The Entrepreneurial State. Debunking Public vs. Private Sector Myths. Revised Edition. UK, USA: Anthem Press.

Mazzoleni, R., \& Nelson, R. R. (2005). The roles of research at universities and public labs in economic catch-up. LEM Working Paper Series, 2006/01, 1-40. Laboratory of Economics and Management, Sant'Anna School of Advanced Studies.

McKelvey, M., Orsenigo, L., Pammolli, F. (2004). Pharmaceuticals analyzed through the lens of a sectoral innovation system. In F. Malerba (Ed.), Sectoral Systems of Innovation: Concepts, Issues and Analyses of Six Major Sectors in Europe (pp. 73-120). Cambridge: Cambridge University Press.

Mowery, D. C. (2011). Learning from one another? International policy 'emulation' and university-industry technology transfer. Industrial and Corporate Change, 20(6), $1827-1853$.

Muscio, A., \& Vallanti, G. (2014). Perceived obstacles to university-industry collaboration: Results from a qualitative survey of Italian academic departments. Industry and Innovation, 21(5), 410-429.

Mürk, I., \& Kalvet, T. (2015). The Role of Research and Development Enterprises in the Estonian Innovation System. Research and Innovation Policy Monitoring Programme (2012-2015): Final Report of the Workpackage 4.3. Estonia: Tallinn University of Technology.

Narula, R., \& Guimón, J. (2010). The R\&D Activity of multinational enterprises in peripheral economies: Evidence from the EU new member states. UNU-MERIT Working Paper Series, 2010-048, 1-32. 
Nature. (2009). Back on the map: Central and Eastern European nations still lag behind Western countries in science. But they are slowly catching up. Nature, 461, 569.

Nelson, A. J. (2012). Putting university research in context: Assessing alternative measures of production and diffusion at Stanford. Research Policy, 41(4), 678-691.

Niinemets, Ü. (2019). Career models and job opportunities for the researchers in Estonia: Where are we coming from, and where are we heading to? In Ü. Niinemets, E. Karo, R. Kattel, R. Villems \& K. Raudvere (Eds.), Estonian Research 2019 (pp. 21-38). Tartu: Estonian Research Council.

OECD. (2017). Patent Statistics (database). Retrieved from http://www.oecdilibrary.org/science-nd-technology/data/oecd-patent-statistics/patents-by-maintechnology-and-by-international-patent-c lassification-ipc_data-00508-en (accessed 17 December 2017).

OECD. (2019). University-Industry Collaboration: New Evidence and Policy Options. Paris: OECD Publishing.

Ooms, W., Werker, C., Caniëls, M. C. J., \& van den Bosch, H. (2015). Research orientation and agglomeration: Can every region become a Silicon Valley? Technovation, 45-46, 78-92.

Pavitt, K. (1984). Sectoral patterns of technical change: Towards a taxonomy and a theory. Research Policy, 13(6), 343-373.

Perez, M. P., \& Sanchez, A. M. (2003). The development of university spin-offs: Early dynamics of technology transfer and networking. Technovation, 23(10), 823-831.

Perkmann, M., Tartari, V., McKelvey, M., Autio, E., Broström, A., D’Este, P., Fini, R., Geuna, A., Grimaldi, R., Hughes, A., Krabel, S., Kitson, M., Llerena, P., Lissoni, F., Salter, A., \& Sobrero, M. (2013). Academic engagement and commercialization: A review of literature on university-industry relations. Research Policy, 42(2), 423-442. 
Philpott, K., Dooley, L., O’Reilly, C., \& Lupton, G. (2011). The entrepreneurial university: Examining the underlying academic tensions. Technovation,31(4), 161-170.

Pisano, G. P. (2006). Science Business: The Promise, the Reality, and the Future of Biotech. Boston, MA: Harvard University Press.

Polt, W., Rammer, C., Schartinger, D., Gassler, H., \& Schibany, A. (2001). Benchmarking Industry-Science Relations in Europe-The Role of Framework Conditions. Project Report. Vienna: Joanneum Research.

Powell, W. W., Owen-Smith, J., \& Colyvas, J. A. (2007). Innovation and emulation: Lessons from American universities in selling private rights to public knowledge. Minerva, 45, $121-142$.

Qiu, S., Liu, X., \& Gao, T. (2017). Do emerging countries prefer local knowledge or distant knowledge? Spillover effect of university collaborations on local firms. Research Policy, 46(7), 1299-1311.

Radosevic, S. (2011). Challenges of converging innovation policies in a multi-tier Europe: A neo-Schumpeterian perspective. In S. Radosevic \& A. Kaderabkova (Eds.), Challenges for European Innovation Policy: Cohesion and Excellence from a Schumpeterian Perspective (pp. 9-46). Cheltenham, UK; Northampton, MA, USA: Edward Elgar Publishers.

Radosevic, S., \& Stancova, K. C. (2015). External dimensions of smart specialization: Opportunities and challenges for trans-regional and transnational collaboration in the EU-13. S3 Working Paper Series, No 09/2015, 1-46. JRC Technical Reports, European Commission.

Rasmussen, E., Mosey, S., \& Wright, M. (2014). The influence of university departments on the evolution of entrepreneurial competencies in spin-off ventures. Research Policy, 43(1), 92-106.

RDI Strategy Knowledge-based Estonia 2002-2006. Retrieved from https://www.digar.ee/arhiiv/en/nlib-digar:12324 (accessed 17 December 2018). 
RDI Strategy Knowledge-based Estonia 2007-2013. Retrieved from http://www.digar.ee/arhiiv/en/books/12129 (accessed 17 December 2018).

RDI Strategy Knowledge-based Estonia 2014-2020. Retrieved from https://www.hm.ee/en/research-and-development (accessed 17 December 2018).

Salter, A. J., and B. R. Martin. (2001). The economic benefits of publicly funded basic research: A critical review. Research Policy, 30(3), 509-532.

Suurna, M. (2011). The developments in the business models of biotechnology in the Central and Eastern European countries: the example of Estonia. Journal of Commercial Biotechnology, 17(1), 84-108.

Suurna, M., \& Kattel, R. (2010). Europeanization of innovation policy in Central and Eastern Europe. Science and Public Policy, 37(9), 646-664.

Teece, D. J., Pisano, G., \& Shuen, A. (1997). Dynamic capabilities and strategic management. Strategic Management Journal, 18(7), 509-533.

Tiits, M., Kalvet, T., \& Mürk, I. (2015). Smart specialization in cohesion countries. Journal of the Knowledge Economy, 6(2), 296-319.

Tödtling, F., \& Trippl, M. (2005). One size fits all? Towards a differentiated regional innovation policy approach. Research Policy, 34(8), 1203-1219.

Ukrainski, K., Kanep, H., Kirs, M., \& Karo, E. (2018). Segregation of EU13 countries in EU framework programmes illuminates important challenges for cohesion policy. CESifo Forum, 19(1), 16-23.

Uyarra, E. (2010). Conceptualizing the regional roles of universities, implications and contradictions. European Planning Studies, 18(8), 1227-1246.

Wong, C.-Y., \& Salmin, M. M. (2016). Attaining a productive structure for technology: The Bayh-Dole effect on university-industry-government relations in developing economy. Science and Public Policy, 43(1), 29-45. 

Appendix 1. Ten Technology Transfer Cases in the Estonian Biotechnology Sector

\begin{tabular}{|c|c|c|c|c|c|c|c|}
\hline $\begin{array}{l}\text { The } \\
\text { case }\end{array}$ & $\begin{array}{l}\text { Type of } \\
\text { venture }\end{array}$ & Field of activity & $\begin{array}{l}\text { The format of } \\
\text { TT }\end{array}$ & $\begin{array}{l}\text { The context of knowledge } \\
\text { provision }\end{array}$ & $\begin{array}{l}\text { The context of knowledge } \\
\text { diffusion }\end{array}$ & $\begin{array}{l}\text { The role of socio- } \\
\text { institutional context }\end{array}$ & $\begin{array}{l}\text { The key strategies and } \\
\text { challenges of academic } \\
\text { ventures }\end{array}$ \\
\hline 1 & $\begin{array}{l}\text { Established } \\
\text { in 1989; } \\
\text { became a } \\
\text { spin-off of } \\
\text { TalTech in } \\
\text { the mid- } \\
2000 \text { s. } \\
\text { Acquired by } \\
\text { MNC in } \\
2008 \text {. }\end{array}$ & $\begin{array}{l}\text { Customorganic } \\
\text { synthesis and } \\
\text { contractR\&D } \\
\text { for the pharma- } \\
\text { ceutical and fine } \\
\text { chemical } \\
\text { industry. }\end{array}$ & $\begin{array}{l}\text { Informal } \\
\text { (staff) }\end{array}$ & $\begin{array}{l}\text { The company's } \\
\text { predecessor started as a } \\
\text { cooperative in the late } \\
\text { 1980s to realize the local } \\
\text { analy tical capabilities in } \\
\text { chemistry-based synthesis } \\
\text { for industrial purposes. }\end{array}$ & $\begin{array}{l}\text { Strong orientation on } \\
\text { international value-chains } \\
\text { together with a reliance on } \\
\text { speed- and cost advantages in } \\
\text { service provision. } \\
\text { The contact with the core } \\
\text { cus tomer es tablished during } \\
\text { one of the first international } \\
\text { R\&D projects. In es sence, the } \\
\text { company became a part of the } \\
\text { Swedish company's res earch } \\
\text { unit over the years. Later, the } \\
\text { collaboration served as a bas is } \\
\text { for the takeover of the } \\
\text { Estonian company. }\end{array}$ & $\begin{array}{l}\text { No direct influence from } \\
\text { Enterprise Es tonia (EAS) } \\
\text { policy ins truments. } \\
\text { Related to Competence } \\
\text { Centre (CC) for Cancer } \\
\text { Research. }\end{array}$ & \multirow{2}{*}{$\begin{array}{l}\text { The success of the particular } \\
\text { businesses has been largely } \\
\text { dependent on the marketing } \\
\text { capabilities, highly } \\
\text { challenging in the context of } \\
\text { reliance on service delivery } \\
\text { and contract research to } \\
\text { multinationals. }\end{array}$} \\
\hline 2 & $\begin{array}{l}\text { Spin-off of } \\
\text { UT, } \\
\text { established } \\
\text { in } 2006 .\end{array}$ & $\begin{array}{l}\text { Provision of } \\
\text { contract } \\
\text { research } \\
\text { services and } \\
\text { small-scale } \\
\text { API/HPAPI } \\
\text { manufacturing; } \\
\text { has developed } \\
\text { its product } \\
\text { platform } \\
\text { (standard } \\
\text { services) by } \\
\text { today. }\end{array}$ & $\begin{array}{l}\text { Informal } \\
\text { (staff) }\end{array}$ & $\begin{array}{l}\text { The local analytical } \\
\text { capabilities in synthetic } \\
\text { organic chemistry. }\end{array}$ & $\begin{array}{l}\text { Strong orientation on } \\
\text { international value-chains } \\
\text { together with a reliance on } \\
\text { speed- and cost ad vantages in } \\
\text { service provision. } \\
\text { The contact of the first client } \\
\text { provided by the potential } \\
\text { investors (venture capitalis ts } \\
\text { from the US). }\end{array}$ & $\begin{array}{l}\text { EAS support measures } \\
\text { vitalduring the period of } \\
\text { economic downturn, but } \\
\text { als o for the opening of } \\
\text { new R\&D lines. } \\
\text { Strong influence by the } \\
\text { Tartu Biotechnology } \\
\text { Park and its services (e.g. } \\
\text { incubation program, } \\
\text { cross-usage of machinery } \\
\text { park by its tenants). } \\
\text { Related to CC on Health } \\
\text { Technologies. }\end{array}$ & \\
\hline
\end{tabular}




\begin{tabular}{|c|c|c|c|c|c|c|c|}
\hline 3 & $\begin{array}{l}\text { Spin-off of } \\
\text { UT and } \\
\text { Estonian } \\
\text { Biocenter, } \\
\text { established } \\
\text { in } 1998 .\end{array}$ & $\begin{array}{l}\text { Development of } \\
\text { DNA tests, } \\
\text { services, and the } \\
\text { respective } \\
\text { technology to } \\
\text { study hereditary } \\
\text { diseases. The } \\
\text { development } \\
\text { and sales of } \\
\text { APEX- } \\
\text { technology } \\
\text { based on a DNA } \\
\text { chip. }\end{array}$ & $\begin{array}{l}\text { Technology + } \\
\text { informal } \\
\text { (staff) }\end{array}$ & $\begin{array}{l}\text { A postdoc period of the } \\
\text { res earch groupleader in } \\
\text { the US important for } \\
\text { knowledge transfer } \\
\text { (knowledge in PCR in } \\
\text { particular). } \\
\text { The initial DNA chip for } \\
\text { breast cancer developed in } \\
\text { the framework of an } \\
\text { international R\&D project } \\
\text { in 1998/1999; the } \\
\text { proceeding methods and } \\
\text { DNA tests developed } \\
\text { considering the needs of } \\
\text { clients (e.g. direction on } \\
\text { eye diseases). }\end{array}$ & $\begin{array}{l}\text { APEX technology included in } \\
\text { the list of services funded by } \\
\text { the Es tonian Health Insurance } \\
\text { Fund - an essential } \\
\text { prerequisite for the service to } \\
\text { be used by medical specialists } \\
\text { nationally. } \\
\text { The regulative environment } \\
\text { for companies providing DNA } \\
\text { tests considerably mild - do } \\
\text { not need to havea medical } \\
\text { laboratory's accreditation. }\end{array}$ & $\begin{array}{l}\text { EAS's supportive role } \\
\text { during the foundation } \\
\text { period of the company, } \\
\text { but also in the } \\
\text { diversification of the } \\
\text { productportfolio (e.g. } \\
\text { developing a separate } \\
\text { oncology portfolio). } \\
\text { Related to CC on Health } \\
\text { Technologies - the CC } \\
\text { has provided exclusive } \\
\text { access to the information } \\
\text { relevant for developing } \\
\text { new tests. The inclusion } \\
\text { of doctors in the work of } \\
\text { CC important to } \\
\text { formulate a need } \\
\text { according to everyday } \\
\text { problems in practice. }\end{array}$ & $\begin{array}{l}\text { As the entry barriers for } \\
\text { companies providing DNA } \\
\text { tests are low and the } \\
\text { competition more } \\
\text { internationalby nature, the } \\
\text { constant widening of the } \\
\text { market share and } \\
\text { diversification of the product } \\
\text { portfolio has been the key } \\
\text { strategy for survival. } \\
\text { The spread at the local market } \\
\text { has been limited by the } \\
\text { reluctance of specialty } \\
\text { physicians to make use of } \\
\text { services relying on genetics } \\
\text { (suppressed by the funding } \\
\text { mechanis ms for the provision } \\
\text { of medical services). }\end{array}$ \\
\hline $4 *$ & $\begin{array}{l}\text { Spin-off of } \\
\text { UT, } \\
\text { established } \\
\text { in } 1999 . \\
\text { Acquired by } \\
\text { MNC in } \\
2013 \text {. }\end{array}$ & $\begin{array}{l}\text { Development } \\
\text { and provision of } \\
\text { new types of } \\
\text { diagnostic } \\
\text { services to the } \\
\text { Estonian } \\
\text { medical sector. }\end{array}$ & $\begin{array}{l}\text { Technology + } \\
\text { informal } \\
\text { (staff) }\end{array}$ & $\begin{array}{l}\text { A postdoc period of the } \\
\text { research group leader in } \\
\text { the US important for } \\
\text { knowledge transfer } \\
\text { (knowledge in PCR in } \\
\text { particular). } \\
\text { The involvement of the } \\
\text { leading target group } \\
\text { (repres entatives of clinics) } \\
\text { in the early stages of } \\
\text { research activities (i.e. } \\
\text { active co-working area) to } \\
\text { formulate a need according } \\
\text { to everyday problems in } \\
\text { practice. }\end{array}$ & $\begin{array}{l}\text { This case has benefitted the } \\
\text { most from public demand } \\
\text { created by the reimburs ement } \\
\text { policy of the Estonian Health } \\
\text { Insurance Fund. After the } \\
\text { mid-2000s, the service has } \\
\text { been funded not only in the } \\
\text { case of specialty physicians } \\
\text { but also in the cas ef family } \\
\text { physicians. } \\
\text { The competence of other } \\
\text { technologies relevant to } \\
\text { providing a full range of } \\
\text { different laboratory services } \\
\text { acquired via the purchase of } \\
\text { the Estonian company HTI } \\
\text { Laboriteenuste AS in } 2006 \text {. }\end{array}$ & $\begin{array}{l}\text { EAS program supportive } \\
\text { during the foundation } \\
\text { period of the company; } \\
\text { influence on the R\&D } \\
\text { projects restricted (the } \\
\text { company's res ources } \\
\text { have been sufficient). } \\
\text { Related to CC for Cancer } \\
\text { Research. }\end{array}$ & $\begin{array}{l}\text { As the company is } \\
\text { experiencing sales revenues } \\
\text { and export capacity not } \\
\text { comparable to the other local } \\
\text { companies of the field, one } \\
\text { can argue that stable access to } \\
\text { the nation-wide demand base } \\
\text { (covering next to specialty } \\
\text { physicians also general } \\
\text { practitioners) has been the } \\
\text { critical success factor not only } \\
\text { at the local markets but also } \\
\text { for scaling-upinternationally. }\end{array}$ \\
\hline
\end{tabular}




\begin{tabular}{|c|c|c|c|c|c|c|c|}
\hline $5 * *$ & $\begin{array}{l}\text { Spin-off of } \\
\text { UT, } \\
\text { established } \\
\text { in } 1999 .\end{array}$ & $\begin{array}{l}\text { Platform } \\
\text { technologies } \\
\text { important for } \\
\text { the development } \\
\text { of new drugs, } \\
\text { vaccines, etc. }\end{array}$ & $\begin{array}{l}\text { Technology }+ \\
\text { informal } \\
\text { (staff) }\end{array}$ & $\begin{array}{l}\text { The core technology of the } \\
\text { company - QMCF } \\
\text { Technology - relying on } \\
\text { the knowledge of virology } \\
\text { and the respective R\&D } \\
\text { projects at UT. } \\
\text { For further developments, } \\
\text { the demand by big pharma } \\
\text { has played a crucial role } \\
\text { (cus tom-tailored services } \\
\text { for protein, antibody, etc., } \\
\text { production). }\end{array}$ & $\begin{array}{l}\text { The company is serving a } \\
\text { specific niche (protein } \\
\text { production in more substantial } \\
\text { quantities within a limited } \\
\text { timeframe) in the local as well } \\
\text { as international value chains. } \\
\text { The recent developments } \\
\text { (including a vaccine and } \\
\text { biological therapeutic for the } \\
\text { Ebola virus) seen primarily as } \\
\text { a way of testing and } \\
\text { demons trating a new pipeline } \\
\text { technology developed in the } \\
\text { group. } \\
\text { The provision of allergen } \\
\text { testing services relying on the } \\
\text { technology bought in. }\end{array}$ & $\begin{array}{l}\text { EAS support relevant for } \\
\text { R\&D projects; in terms } \\
\text { of the foundation, see } \\
\text { also the previous case. } \\
\text { Related to CC on Health } \\
\text { Technologies. }\end{array}$ & $\begin{array}{l}\text { The competitive advantage } \\
\text { relies upon the development } \\
\text { of specific technology } \\
\text { platforms as opposed to the } \\
\text { production of biological drug } \\
\text { candidates. } \\
\text { The company has managed to } \\
\text { position itself as a specialized } \\
\text { service provider in the global } \\
\text { value chains, whereas the } \\
\text { codification and protection of } \\
\text { knowledge are considered } \\
\text { neither cost-efficient nor } \\
\text { neces sary. }\end{array}$ \\
\hline $6 * * *$ & $\begin{array}{l}\text { Contractual } \\
\text { relationships } \\
\text {, which led } \\
\text { to the } \\
\text { establishmen } \\
\text { t of a branch } \\
\text { office in } \\
\text { Tartu in } \\
1999 .\end{array}$ & $\begin{array}{l}\text { Development of } \\
\text { DNA vaccines } \\
\text { and gene } \\
\text { therapy. The } \\
\text { centralfocus of } \\
\text { the company } \\
\text { has been on the } \\
\text { development of } \\
\text { a therapeutic } \\
\text { HIV vaccine } \\
\text { that would pass } \\
\text { Phase II clinical } \\
\text { trials. }\end{array}$ & $\begin{array}{l}\text { Informal } \\
\text { (specific } \\
\text { capabilities) }\end{array}$ & $\begin{array}{l}\text { Contract research to a } \\
\text { Finnish company, relying } \\
\text { on the specific competence } \\
\text { prevalent in the research } \\
\text { group at UT (i.e. DNA } \\
\text { vector analysis). } \\
\text { The research group leader } \\
\text { had a joint publication } \\
\text { together with one of the } \\
\text { scientists of the company, } \\
\text { in which the underlying } \\
\text { technology for the vaccine } \\
\text { was described. The } \\
\text { ownership of the } \\
\text { technology remains } \\
\text { outside Es tonia. }\end{array}$ & If at all, the quality/costratio. & $\begin{array}{l}\text { Funding from TEKES } \\
\text { (Finnish innovation } \\
\text { agency). }\end{array}$ & \multirow[t]{2}{*}{$\begin{array}{l}\text { The initiatives underquestion } \\
\text { are related to the } \\
\text { pharmaceutical industry, } \\
\text { where the prevalence of "exit- } \\
\text { strategy" in business models } \\
\text { as well as following the } \\
\text { industry's investmentinterests } \\
\text { as set by the global level (e.g. } \\
\text { research on the cancer } \\
\text { treatment as a possible "gold } \\
\text { mine") stand out. } \\
\text { The previous also explains the } \\
\text { separation of service delivery } \\
\text { and R\&D activities (including } \\
\text { IP) as a prevalentbusiness } \\
\text { model in these particular } \\
\text { cases. }\end{array}$} \\
\hline 7 & $\begin{array}{l}\text { Contractual } \\
\text { relationships }\end{array}$ & $\begin{array}{l}\text { A range of } \\
\text { potential new } \\
\text { technologies, }\end{array}$ & $\begin{array}{l}\text { Informal } \\
\text { (staff) }\end{array}$ & $\begin{array}{l}\text { Contract res earch to a US } \\
\text { partner as a basis for }\end{array}$ & $\begin{array}{l}\text { Business model relying on the } \\
\text { allocation of different R\&D } \\
\text { activities / specializations to a }\end{array}$ & $\begin{array}{l}\text { Influenced substantially } \\
\text { by the side of EAS - a } \\
\text { significant degree of }\end{array}$ & \\
\hline
\end{tabular}




\begin{tabular}{|c|c|c|c|c|c|c|c|}
\hline & $\begin{array}{l}\text { Some } \\
\text { enterprises } \\
\text { of the Group } \\
\text { have been } \\
\text { formed } \\
\text { legally as } \\
\text { spin-offs of } \\
\text { TalTech, } \\
\text { established } \\
\text { in } 2003 \text {. }\end{array}$ & $\begin{array}{l}\text { products, and } \\
\text { services in the } \\
\text { process (from } \\
\text { cell therapy and } \\
\text { stems cells to } \\
\text { cosmetic and } \\
\text { dermatology } \\
\text { and } \\
\text { microbiological } \\
\text { testing of the } \\
\text { environment). }\end{array}$ & & $\begin{array}{l}\text { founding the first } \\
\text { enterprise. } \\
\text { In principle, the company } \\
\text { could have been } \\
\text { established anywhere in } \\
\text { terms of location. }\end{array}$ & $\begin{array}{l}\text { number of different } \\
\text { subsidiaries in the Group } \\
\text { As EMA authorization is } \\
\text { required for the marketing of } \\
\text { drugs and diagnostics, } \\
\text { restriction to the local market } \\
\text { has not been considered } \\
\text { reas onable. }\end{array}$ & $\begin{array}{l}\text { R\&D grant allocations } \\
\text { converged into the hands } \\
\text { of this Group. } \\
\text { The Estonian } \\
\text { Development Fund } \\
\text { (currently the portfolio of } \\
\text { investments taken over } \\
\text { by SmartCap AS) acts as } \\
\text { a partner in several } \\
\text { companies of this Group. } \\
\text { Related to CC for Cancer } \\
\text { Research. }\end{array}$ & \\
\hline 8 & $\begin{array}{l}\text { Students' } \\
\text { spin-off of } \\
\text { UT, } \\
\text { established } \\
\text { in } 2008 . \\
\text { The } \\
\text { company } \\
\text { founded a } \\
\text { subsidiary in } \\
\text { Germany in } \\
2012 .\end{array}$ & $\begin{array}{l}\text { Development of } \\
\text { point-of-care } \\
\text { medical devices } \\
\text { to detect } \\
\text { infectious } \\
\text { diseases. }\end{array}$ & $\begin{array}{l}\text { Informal } \\
\text { (staff) }+ \\
\text { contracts to } \\
\text { R\&D } \\
\text { institutions }\end{array}$ & $\begin{array}{l}\text { The product's technology } \\
\text { base (is othermal } \\
\text { amplification) does not } \\
\text { originate fromEstonia. } \\
\text { In the second phase of } \\
\text { development, the } \\
\text { collaboration has been } \\
\text { intensified more and most } \\
\text { with the Fraunhofer } \\
\text { Institute for Cell Therapy } \\
\text { and Immunology (IZI). } \\
\text { The prototype of the } \\
\text { productlaunched in } 2017 \text {. }\end{array}$ & $\begin{array}{l}\text { The secondary activities } \\
\text { (sales) relevant for gathering } \\
\text { experience but als o additional } \\
\text { funding. } \\
\text { The regulatory environment in } \\
\text { the case of this medical } \\
\text { product remains somewhat } \\
\text { fuzzy (in particular, to which } \\
\text { extent the validations need to } \\
\text { be carried out). In terms of } \\
\text { FDA authorization, a } \\
\text { simplified sys temis appealed } \\
\text { for. }\end{array}$ & $\begin{array}{l}\text { Since the foundation of } \\
\text { the company was } \\
\text { influenced substantially } \\
\text { by the side of EAS (e.g. } \\
\text { R\&D grant allocations, } \\
\text { support for covering } \\
\text { patent studies). } \\
\text { The Estonian } \\
\text { DevelopmentFund acts } \\
\text { as a partner in the } \\
\text { company. } \\
\text { Significant financial } \\
\text { support was also } \\
\text { provided by the } \\
\text { Development Bank of } \\
\text { Saxony, AufbauBank } \\
\text { SAB. } \\
\text { No relations to any CCs } \\
\text { in Estonia. }\end{array}$ & $\begin{array}{l}\text { Following the "born global" } \\
\text { kind of aspirations fromthe } \\
\text { very beginning, the company } \\
\text { has moved into the hands of } \\
\text { foreign capitalby now. }\end{array}$ \\
\hline 9 & $\begin{array}{l}\text { R\&D } \\
\text { collaboration } \\
\text { platform, } \\
\text { founded }\end{array}$ & $\begin{array}{l}\text { Development of } \\
\text { technologies for } \\
\text { metabolic } \\
\text { engineering of }\end{array}$ & $\begin{array}{l}\text { Informal } \\
\text { (staff) from } \\
\text { TalTech }\end{array}$ & $\begin{array}{l}\text { The related research } \\
\text { activities go back to the } \\
\text { early-1990s. }\end{array}$ & $\begin{array}{l}\text { Financial independenceand } \\
\text { making money havebeen the } \\
\text { key aims from the very } \\
\text { beginning. }\end{array}$ & $\begin{array}{l}\text { Not dependent on EAS } \\
\text { support. The state } \\
\text { support has been used to } \\
\text { build up the }\end{array}$ & $\begin{array}{l}\text { The maturity of the food } \\
\text { industry has provided a more } \\
\text { stable basis for defining } \\
\text { specific applications and }\end{array}$ \\
\hline
\end{tabular}




\begin{tabular}{|c|c|c|c|c|c|c|c|}
\hline & $\begin{array}{l}\text { jointly by } \\
\text { TalTech and } \\
6 \text { partner } \\
\text { companies } \\
\text { in } 2004 .\end{array}$ & $\begin{array}{l}\text { microorganisms } \\
\text { together with } \\
\text { the potential } \\
\text { applications in } \\
\text { agro-food sector } \\
\text { and primary } \\
\text { production, but } \\
\text { also in health } \\
\text { care, and for } \\
\text { environmental } \\
\text { solutions. }\end{array}$ & & $\begin{array}{l}\text { The applied research has } \\
\text { embodied a strong } \\
\text { fundamental focus (to } \\
\text { work out new methods for } \\
\text { cell diagnostics and } \\
\text { modeling), especially as } \\
\text { the most valuable partners } \\
\text { for CCFFT have been } \\
\text { those of internationally } \\
\text { well-recognized } \\
\text { corporations such as } \\
\text { DuPont, Lallemand and } \\
\text { Valio but also Applikon } \\
\text { (in terms of the software), } \\
\text { etc. }\end{array}$ & $\begin{array}{l}\text { In strategic terms, } \\
\text { participation in international } \\
\text { R\&D projects; a certain } \\
\text { degree of stability provided by } \\
\text { collaboration with the local } \\
\text { (mature food) industry. }\end{array}$ & $\begin{array}{l}\text { infrastructure and train } \\
\text { the staff; the sales from } \\
\text { its activity havecovered } \\
\text { the exploitation of the } \\
\text { center. }\end{array}$ & $\begin{array}{l}\text { formalizing these transfers } \\
\text { through patents and licenses. } \\
\text { The harmonization with EU } \\
\text { regulations during the late } \\
\text { 1990s and early 2000s acted } \\
\text { as a force-mechanism for } \\
\text { greater cooperation between } \\
\text { the localfood industry and } \\
\text { R\&D institutions (including } \\
\text { with CCs), while many small } \\
\text { companies, incl. Vastse- } \\
\text { Kuuste Dairy Association } \\
\text { mentioned below, were closed } \\
\text { down. }\end{array}$ \\
\hline 10 & $\begin{array}{l}\text { Patenting } \\
\text { and license } \\
\text { agreements } \\
\text { related to } \\
\text { UT (patent } \\
\text { granted in } \\
\text { Estonia in } \\
\text { 2005; in } \\
\text { other } \\
\text { countries } \\
\text { (Russia, US, } \\
\text { and Europe) } \\
\text { between } \\
2006 \text { and } \\
2010 .\end{array}$ & $\begin{array}{l}\text { Upgrading local } \\
\text { mature-food } \\
\text { industry; } \\
\text { development of } \\
\text { a wide range of } \\
\text { productlines in } \\
\text { functional food. }\end{array}$ & $\begin{array}{l}\text { Commercia- } \\
\text { lization of IP } \\
\text { for probiotic } \\
\text { bacteria } \\
\text { Lactobacillus } \\
\text { fermentum } \\
\text { ME-3 (in case } \\
\text { of the } \\
\text { company) } \\
\text { Patents for } \\
\text { Tensia \& } \\
\text { Inducia strains } \\
+ \text { informal } \\
\text { (staff) from } \\
\text { UT (in case of } \\
\text { establishing } \\
\text { CC) }\end{array}$ & $\begin{array}{l}\text { The related research } \\
\text { activities go back to } 1995 \\
\text { when the research group } \\
\text { participated in the Swedish } \\
\text { Wellcome Trust funded } \\
\text { R\&D project to explore the } \\
\text { causality between the } \\
\text { living environments and } \\
\text { the emergence of allergies. } \\
\text { Later on, the collection of } \\
\text { bacteria has served as an } \\
\text { important advantage to be } \\
\text { involved in different } \\
\text { international R\&D } \\
\text { projects. }\end{array}$ & $\begin{array}{l}\text { Active engagement by the side } \\
\text { of the UT's technology } \\
\text { trans fer office - one pers on } \\
\text { has been dealing with the } \\
\text { commercialization of ME-3 } \\
\text { bacteria for years. Today, one } \\
\text { company in Estonia holds the } \\
\text { respective exclusive license. } \\
\text { The direction on food } \\
\text { supplements relying upon } \\
\text { international partnerships. } \\
\text { The regulative environment in } \\
\text { the EU not supportive(claims } \\
\text { on probiotics not approved by } \\
\text { the European Food Safety } \\
\text { Authority). }\end{array}$ & $\begin{array}{l}\text { EAS support has served } \\
\text { as an important basis for } \\
\text { building up the specific } \\
\text { manufacturing capability } \\
\text { and realizing the pilot } \\
\text { project (Vastse-Kuuste } \\
\text { Dairy As sociation } \\
\text { experimenting with ME- } \\
3 \text { bacteria in its branded } \\
\text { Heart Cheese). } \\
\text { Related strongly to the } \\
\text { Bio-CC of Healthy Dairy } \\
\text { Products. }\end{array}$ & $\begin{array}{l}\text { During the whole process, the } \\
\text { negotiations with more than } \\
200 \text { corporations have been } \\
\text { held, whereas many partners } \\
\text { have exited the market, and } \\
\text { currently, only a few } \\
\text { agreements are active. } \\
\text { The pilot project was crucial } \\
\text { to establish confidence in the } \\
\text { undertaking by the side of the } \\
\text { business ector (including in } \\
\text { the company, holding the } \\
\text { exclusive license } \\
\text { agreement currently). }\end{array}$ \\
\hline
\end{tabular}

Note: *,**,*** are all related to one single person in essence. TalTech - Tallinn University of Technology; UT - University of Tartu; CC - Competence Centre; EAS -

Enterprise Estonia; $M N C$-Multinational Company.

Source: compiled by Authors. 
